\title{
SPANXN5 wt Allele
}

National Cancer Institute

\section{Source}

National Cancer Institute. SPANXN5 wt Allele. NCI Thesaurus. Code C93002.

Human SPANXN5 wild-type allele is located in the vicinity of Xp11.22 and is approximately

$2 \mathrm{~kb}$ in length. This allele, which encodes sperm protein associated with the nucleus on the $\mathrm{X}$ chromosome $\mathrm{N} 5$ protein, may play a role in the maturation of male gametes. 